九州大学学術情報リポジトリ

Kyushu University Institutional Repository

Effects of the Application of Water Treatment Sludge on Growth of Lettuce (Lactuca sativa L.) and Changes in Soil Properties

Oh, Taek-Keun

Biotron Institute, Graduate School of Bioresource and Bioenvironmental Sciences, Kyushu University

Nakaji, Kei

Laboratory of Agricultural Ecology, Division of Agricultural Ecology, Department of Plant Resource, Faculty of Agriculture, Kyushu University

Chikushi, Jiro

Biotron Institute, Graduate School of Bioresource and Bioenvironmental Sciences, Kyushu University

Park, Seok-Gon

Tropical Agriculture Institute, Graduate School of Social and Cultural Studies, Kyushu University

https://doi.org/10.5109/17795

出版情報：九州大学大学院農学研究院紀要. 55 (1)，pp.15-20，2010-02-26. Faculty of Agriculture， Kyushu University

バージョン :

権利関係 : 


\title{
Effects of the Application of Water Treatment Sludge on Growth of Lettuce (Lactuca sativa L.) and Changes in Soil Properties
}

\author{
Taek-Keun OH$^{1}$, Kei NAKAJI ${ }^{2}$, Jiro CHIKUSHI ${ }^{1 *}$ \\ and Seok-Gon PARK ${ }^{3}$ \\ Biotron Institute, Kyushu University, 6-10-1, Hakozaki, Higashi-ku, \\ Fukuoka 812-8581, Japan \\ (Received October 19, 2009 and accepted November 19, 2009)
}

\begin{abstract}
The effectiveness of the application of water treatment sludge (WTS) to soils for cultivating a vegetable was examined. Initially, properties of original WTS, decomposed granite (DG) soil and volcanic ash (VA) soils were investigated, including physical properties of water content, porosity, dry density, saturated hydraulic conductivity, and texture and chemical properties of $\mathrm{pH}, \mathrm{EC}$, organic matter content, CEC, phosphate adsorption coefficient, and $\mathrm{C}, \mathrm{N}$, and H contents. Lettuce (Lactuca satuva L.) was grown in a phytotron room at a temperature of $20^{\circ} \mathrm{C}$ using pots filled with DG soil and VA soil mixed with WTS at rates of 0 (N-P-K standard fertilizer application), 0, 4.5, and $9.0 \mathrm{Mg} \mathrm{ha}^{-1}$. The yields of lettuce grown for the treatments of 4.5 , and $9.0 \mathrm{Mg} \mathrm{ha}^{-1}$ sludge addition in VA soil were lower by $38 \%$ and $7 \%$ compared with the treatment of $0 \mathrm{Mg} \mathrm{ha}^{-1}$ sludge addition, respectively. However, the yield in DG soil was significantly higher by $72 \%$ (4.5 $\mathrm{Mg} \mathrm{ha}^{-1}$ WTS addition) and 71\% (9.0 $\mathrm{Mg} \mathrm{ha}^{-1}$ WTS addition) compared with $0 \mathrm{Mg}^{-1}$ sludge addition, respectively. These results suggest that land application of WTS may act positively to organic matterdeficient soils like DG soil, but negatively to fertile soil like VA soil.
\end{abstract}

\section{INTRODUCTION}

Water treatment sludge (WTS) is produced in conventional drinking-water treatment processes as sedimentation including suspended and dissolved solids, organic matter, and other suspensions. It is estimated that an astonishing amount of 10,000 tons per day of WTS is produced in the world (Dharmappa et al., 1997) and the quantity of WTS may be continually increasing with the industrial development and with the improvement of human life (Wang, 1997). For example, in Europe, several millions of tons of WTS are produced every year, and this may double by the next decade (Basibuyuk and Kalat, 2004). In Ireland, a twofold increase from the current value of 15,000 to 18,000 tons per year has been predicted by the end of the next decade (Zhao et al., 2006). A 2006 survey of 565 water treatment plants in Korea indicated that 2,507 tons of WTS is produced every day (Ministry of Environment in Korea, 2005). Due to these facts, the safe disposal of WTS has been becoming one of the main environmental concerns throughout the world due to the enormous quantity generated, the associated costs, and appropriate regulations. Typically, disposal techniques such as soil application, ocean dumping, land filling, and incineration have been tried (Sánchez Monedero et al., 2004). For these disposal practices, however, strict environmental regulation, known as the London Dumping Convention (London

Biotron Institute, Graduate School of Bioresource and Bioenvironmental Sciences, Kyushu University

2 Laboratory of Agricultural Ecology, Division of Agricultural Ecology, Department of Plant Resource, Faculty of Agriculture, Kyushu University

3 Tropical Agriculture Institute, Graduate School of Social and Cultural Studies, Kyushu University

* Corresponding author (E-mail: chiku2@agr.kyushu-u.ac.jp)
Convention 1972 and the 1996 Protocol), has been imposed. Therefore, with a continual increase in the production of WTS, legislative and economic actions have been aiming at the avoidance of environmental contamination and the reuse of WTS (Babatunde and Zhao, 2007). In particular, it has been advocated that WTS could become a reusable product with great commercial potential (Rensburg and Morgenthal, 2003). A number of constructive attempts and research efforts have been done particularly in recent years to reuse WTS in various beneficial ways such as coagulant and/or adsorbent for cleaning contaminants water, building materials of brick and concrete, land applications to improve soil quality, and other uses of animal feed, etc.

The land application is suggested to be one of the most economical disposal methods and has attracted the interest of environmental engineers and scientists (Kim et al., 2002). Because WTS predominantly contains sediment and humic substances in the original water, it looks like fine-textured soil and may be suitable for reuse as a soil substitute (Elliott and Dempsey, 1991; Elliott and Singer, 1998). Reuse of WTS for agricultural purposes has many beneficial effects, namely, supplying nutrients of nitrogen, phosphorus, and micronutrients, etc to the crops (Heil and Barbarick, 1989; Basta et al., 2000), improving soil physical properties (Moodley and Hughes, 2005) and increasing soil organic matter content (Rengasamy et al., 1980; USEPA, 1983). For these reasons, several research efforts in the land application of WTS taken from water treatment plants have been carried out. Rengasamy et al. (1980) found that maize (Zea mays L.) grown in WTS amended soil gave the highest yield at the WTS application rates of $2 \mathrm{Mg} \mathrm{ha}^{-1}$ treatment. Bugbee and Frink (1985) applied WTS at rates of 0 to $670 \mathrm{~g} \mathrm{~kg}^{-1}$ and found that the water holding capacity in the growing media increased. Geertsema et 
al. (1994) applied the rates of alum sludge up to $2.5 \mathrm{~kg}$ $\mathrm{kg}^{-1}$ and reported that the sludge had no significant effects on the retention properties of the soil in 30 months after application. Elliott and Singer (1988) examined tomato growth (Lycospersicum esculentum) in conditions of added ferric-WTS at the rates of 0 to $100 \mathrm{~g} \mathrm{~kg}^{-1}$ to a silt loam and reported an increased growth that may be attributed to the reduction of $\mathrm{Al}$ and $\mathrm{Mn}$ toxicity in the soil followed by the increase of $\mathrm{pH}$ due to WTS application. Heil and Barbarick (1989) also applied the sludge at the rates of 0 to $25 \mathrm{~g} \mathrm{~kg}^{-1}$ to grow sorghum-sudangrass (Sorghum bicolor L. Moench-S. sudanense) and they found that a low application rate $\left(5 \mathrm{~g} \mathrm{~kg}^{-1}\right)$ gave the highest yield without causing $\mathrm{P}$ deficiency. Skene et al. (1995) examined the growth of the foliage of broad beans (Phaseolus vulgaris) grown in a soil treated with alum sludge applied at the rates of 20,40 , and $100 \mathrm{~g} \mathrm{~kg}^{-1}$ and concluded that the alum sludge may potentially improve growing media. Basta et al. (2000) investigated the phosphorus uptake by bermudagrass (Cynodon dactylon) grown in three different sludge amended soils. The authors found that $\mathrm{P}$ addition of $0.2 \mathrm{~g} \mathrm{P} \mathrm{kg}^{-1}$ had not increased the plant availability of $\mathrm{P}$ on the WTR, although $\mathrm{P}$ addition increased the yield and tissue $\mathrm{P}$ concentrations of bermudagrass grown on soil. On the effect of the sludge application of between 0 and $1280 \mathrm{Mg} \mathrm{ha}^{-1}$ for four South Africa soils, Moodley and Hughes (2005) suggest that the saturated hydraulic conductivity of the soils and total porosity increase linearly with the application rate due to the decrease in bulk density. On top of that, the high organic matter content of the sludge can improve soil physical properties such as soil aeration, water holding capacity, and aggregate stability (Logan and Harrison, 1995; Aggelides and Londra, 2000).

However, unlike the case of sewage sludge, the studies on the land application of WTS is lacking for now. Thus, we examined the suitability of WTS as soil substitutes by investigating soil properties and by comparing growth of lettuce cultivated in a volcanic ash soil and decomposed granite soil.

\section{MATERIALS AND METHODS}

\section{Preparation of WTS and soils}

WTS was available from a drinking-water treatment plant located at Kurume, Fukuoka prefecture, Japan. Poly aluminum chloride $\left[\mathrm{Al}_{2}(\mathrm{OH})_{3} \mathrm{Cl}_{3}\right]$ was used as a precipitation agent for the water treatment. Two types of soil, volcanic ash (VA) soil and decomposed granite (DG) soil, were used for cultivation media. The VA soil was obtained from the Nagasaki agriculture \& forestry experiment station, at Nagasaki Prefecture, Japan and the DG soil was obtained randomly from surface layers $(0-30 \mathrm{~cm})$ of the uncultivated area (mountain soil) in Koga, Fukuoka Prefecture, Japan. All the samples were air-dried and gently crushed with a rubber hammer. The crushed samples were then sieved to extract particles smaller than $2 \mathrm{~mm}$ diameter, being used for plant growth experiment and physico-chemistry analysis.

\section{Design of pot experiment with lettuce (Lactuca sativa L.)}

Lettuce (Lactuca satuva L.) was selected for plant cultivation here because it is frequently planted both by farmers and by hobby gardeners and it is inexpensive to grow. Further, lettuce is a vegetable of great consumption in Korea and can be re-cultivated in greenhouses at intervals of about 10 weeks. Lettuce seeds were sown in multicell flats (plug trays) filled with the vermiculite of pH 7 and placed in the phytotron greenhouse of the Biotron Institute in Kyushu University, Japan. After a four-week planting, lettuce seedlings were transplanted into the 1/5000a Wagner pots containing soil mixed with WTS. The dried WTS was mixed with each soil at three rates $(\mathrm{w} / \mathrm{w})$ in the pots of 0,25 , and $50 \%$ (corresponding to $0,4.5$, and $9.0 \mathrm{Mg} \mathrm{ha}^{-1}$, respectively). Alternatively, control pots (or so-called blank) containing only each soil and chemical fertilizers $\left(\mathrm{N}-\mathrm{P}_{2} \mathrm{O}_{5}-\mathrm{K}_{2} \mathrm{O}=1.6-1.6-1.6 \mathrm{~kg}\right.$ $\mathrm{ha}^{-1}$ ) were also used for the comparison. All the pots were arranged in a complete randomized plot design and triplicate pots for each treatment, i.e., totally 24 pots, were placed in the greenhouse. The greenhouse conditions during the experiment were: average photoperiod, $13 \mathrm{~h}$; average relative humidity, 70\%; and average temperatures, $20^{\circ} \mathrm{C}$. Tap water was added as responding to the dryness of soil and plant; the pots could drain freely into polyethylene saucers. Number, length, and width of lettuce leaves were measured. After the harvesting, the lettuce was washed with running water to remove the soil before measuring fresh weight of the shoots and roots. The cultivation test was started in June 14, 2007 and ended on August 12, 2007.

For nutrient analysis of plants, samples were ovendried at $60{ }^{\circ} \mathrm{C}$ for $24 \mathrm{~h}$ and ground in a mill with a titanium rotor. Thereafter, the nutrients ( $\mathrm{K}, \mathrm{Ca}, \mathrm{P}$, and $\mathrm{Mg}$ ) of shoots and roots were determined by ICP-emission spectrometry (Optima 3000 DV, Perkin Elmer). Nitrogen content in shoots and roots was determined by digesting the samples in sulfuric acid $\left(\mathrm{H}_{2} \mathrm{SO}_{4}\right)$ followed by analysis of total-N by the Kjeldahl method (Bremner and Mulvaney, 1982).

\section{Analysis of physico-chemical properties}

The $\mathrm{pH}$ and electrical conductivity (EC) of the original soils and soil mixtures (soils and sludge) were measured before and after the cultivation experiment in a 1:5 suspension of soil in distilled water using a $\mathrm{pH}$ meter (F-21, HORIBA) and an EC meter (CM-5S, TOA Electronics). Furthermore, the following physical and chemical analyses were performed on each soil sample and the sludge: carbon $(\mathrm{C})$, hydrogen $(\mathrm{H})$ and nitrogen (N) composition by the elemental analyzer (Yanaco CHN Coder MT-5); chemical compositions by X-ray fluorescence analysis (Shimadzu, EDX - 800); organic matter by loss on ignition (LOI) method; cation exchange capacity (CEC) by the Schollenberger method (Schollenberger and Simon, 1945) with $1 \mathrm{~N} \mathrm{CH}_{3} \mathrm{COONH}_{4}$ at pH 7; saturated hydraulic conductivity by the falling-head method; particle size distribution by hydrometer method (Gee and Or, 2002); particle density by pycnometer method 
(Flint and Flint; 2002); available phosphorus by the Bray No. 2 method; heavy metals and exchangeable cations by inductively coupled plasma-optical emission spectrophotometer (ICP-OES, Varian 730-ES); and absorption coefficient phosphorus by the ammonium phosphate method (Japanese Society of Soil Science and Plant Nutrition, 2003).

\section{Analysis of Statistics}

Statistical analysis of the results from the pot experiment was performed with the aid of an SAS version 9.1, and Duncan's multiple range tests estimated the significance of statistical mean difference among the treatments. Differences with a probability larger than 95\% were taken as significant.

\section{RESULTS AND DISCUSSION}

\section{Physico-chemical properties}

The main chemical compositions of the sludge and soil samples used in this experiment were summarized in Table 1. The chemical compositions of WTS shows that aluminum oxide expressed by $\mathrm{Al}_{2} \mathrm{O}_{3}$ is dominant with $49.9 \%$ in mass and the other oxides decreased in order of $\mathrm{SiO}_{2}, \mathrm{Fe}_{2} \mathrm{O}_{3}, \mathrm{CaO}$, and $\mathrm{K}_{2} \mathrm{O}$. The VA soil and $\mathrm{DG}$ soil consisted of higher $\mathrm{SiO}_{2}$ and $\mathrm{Fe}_{2} \mathrm{O}_{3}$ and lower $\mathrm{Al}_{2} \mathrm{O}_{3}$ than WTS.

Physico-chemical properties of original soils and WTS were analysed (Table 2). The water content and organic matter content of the VA soil were $26.3 \%$ and $25.0 \%$, respectively, which were higher than those of the DG soil and WTS. The $\mathrm{pH}$ of the VA soil and DG soil were pH 5.6 and pH 7.0, respectively. The texture of WTS was classified as a sand soil, in which the portions of sand, silt, and clay were $92.1,6.9$, and $1.0 \%$, respectively. WTS also had high CEC (14.5 cmolc $\mathrm{kg}^{-1}$ ), weak acid ( $\mathrm{pH}$ 6.2), and high $\mathrm{C} / \mathrm{N}$ ratio (22.0\%). As WTS usually contains organic matter (Clapp et al., 1986), land application of WTS also contributes to the increase in the organic matter content in soils. Therefore, the high organic matter (15.5\%) of WTS may become a valuable resource for lettuce cultivation when soil application is conducted.

Table 1. Principal chemical compositions

\begin{tabular}{cccc} 
Table 1. Principal chemical compositions & (Unit : wt. \%) \\
\hline Composition & WTS & VA soil & DG soil \\
\hline $\mathrm{Al}_{2} \mathrm{O}_{3}$ & 49.90 & 17.60 & 11.80 \\
$\mathrm{SiO}_{2}$ & 39.97 & 65.59 & 73.41 \\
$\mathrm{Fe}_{2} \mathrm{O}_{3}$ & 5.62 & 11.60 & 6.21 \\
$\mathrm{CaO}$ & 1.41 & 1.42 & 3.33 \\
$\mathrm{~K}_{2} \mathrm{O}$ & 1.36 & 1.28 & 2.51 \\
$\mathrm{TiO}_{2}$ & 0.60 & 1.34 & 0.86 \\
$\mathrm{SO}_{3}$ & 0.45 & 0.33 & n.d. \\
$\mathrm{P}_{2} \mathrm{O}_{5}$ & 0.36 & 0.52 & n.d. \\
$\mathrm{MnO}$ & 0.25 & 0.29 & 0.13 \\
$\mathrm{MgO}$ & n.d. & n.d. & 1.63 \\
\hline
\end{tabular}

n.d. : not detected

Table 2. Physico-chemical properties

\begin{tabular}{|c|c|c|c|}
\hline Properties & WTS & VA soil & DG soil \\
\hline Water content (\%) & 12.1 & 26.3 & 3.0 \\
\hline Porosity (\%) & 64.0 & 66.7 & 43.6 \\
\hline Particle density $\left(\mathrm{g} \mathrm{cm}^{-3}\right)$ & 2.5 & 2.4 & 2.8 \\
\hline Dry density $\left(\mathrm{g} \mathrm{cm}^{-3}\right)$ & 0.9 & 0.8 & 1.6 \\
\hline Saturated permeability coefficient $\left(\mathrm{cm} \mathrm{s}^{-1}\right)$ & $1.02 \times 10^{-3}$ & $5.51 \times 10^{-4}$ & $4.29 \times 10^{-3}$ \\
\hline Texture & Sand & Sandy loam & Sand \\
\hline Sand (\%) & 92.1 & 75.7 & 91.8 \\
\hline Silt (\%) & 6.9 & 21.0 & 6.8 \\
\hline Clay (\%) & 1.0 & 3.3 & 1.4 \\
\hline pH (1:5 soil:water) & 6.2 & 5.6 & 7.0 \\
\hline EC (1:5 soil:water, $\left.\mathrm{dS} \mathrm{m}^{-1}\right)$ & 1.3 & 1.6 & 0.1 \\
\hline Organic matter (\%) & 15.5 & 25.0 & 1.9 \\
\hline $\mathrm{CEC}\left(\mathrm{cmol}_{\mathrm{c}} \mathrm{kg}^{-1}\right)$ & 14.5 & 37.7 & 8.7 \\
\hline Total nitrogen $(\%)$ & 0.3 & 0.6 & n.d. \\
\hline \multicolumn{4}{|l|}{ Exchangeable cations $\left(\mathrm{cmol}_{\mathrm{c}} \mathrm{kg}^{-1}\right)$} \\
\hline Potassium (K) & 0.4 & 1.3 & 0.1 \\
\hline Calcium (Ca) & 6.3 & 9.8 & 8.5 \\
\hline Magnesium (Mg) & 0.4 & 2.4 & 1.5 \\
\hline Available $\mathrm{P}_{2} \mathrm{O}_{5}\left(\mathrm{mg} \mathrm{kg}^{-1}\right)$ & 71.2 & 36.6 & 45.6 \\
\hline Total phosphorous $\left(\mathrm{mg} \mathrm{kg}^{-1}\right)$ & 1207.6 & 651.9 & 1150.6 \\
\hline Phosphate absorption coefficient $\left(\mathrm{g} \mathrm{P}_{2} \mathrm{O}_{5} \mathrm{~kg}^{-1}\right)$ & 26.1 & 26.3 & 24.4 \\
\hline \multicolumn{4}{|l|}{ Element content (\%) } \\
\hline Carbon $(\mathrm{C})$ & 6.6 & 8.9 & n.d. \\
\hline Nitrogen $(N)$ & 0.3 & 0.6 & n.d. \\
\hline Hydrogen (H) & 1.8 & 2.5 & 0.4 \\
\hline $\mathrm{C} / \mathrm{N}$ ratio & 22.0 & 14.8 & - \\
\hline
\end{tabular}

n.d. : not detected 
Table 3. Heavy metal concentrations of the sludge used for experiments and maximum allowable limits

(Unit : $\mathrm{mg} \mathrm{kg}^{-1}$ )

\begin{tabular}{lccc}
\hline \multirow{2}{*}{ Properties } & WTS & \multicolumn{2}{c}{ Maximum allowable limits } \\
\cline { 3 - 4 } & & Korea $^{\mathrm{a}}$ & U. S. A. ${ }^{\mathrm{b}, \mathrm{c}}$ \\
\hline Chromium (Cr) & n.d. & 300 & $3000^{\mathrm{c}}$ \\
Copper (Cu) & 14 & 300 & $4300^{\mathrm{b}}$ \\
Nickel (Ni) & n.d. & 50 & $420^{\mathrm{b}}$ \\
Lead (Pb) & n.d. & 150 & $840^{\mathrm{b}}$ \\
Zinc (Zn) & 24 & 900 & $2500^{\mathrm{b}}$ \\
Arsenic (As) & n.d. & 50 & $75^{\mathrm{b}}$ \\
Cadmium (Cd) & n.d. & 5 & $85^{\mathrm{b}}$ \\
\hline
\end{tabular}

${ }^{a}$ source : Republic of Korea (2004).

${ }^{\mathrm{b}}$ source : Adapted from U.S. EPA (1995)

CCL (ceiling concentration limits) $=$ maximum concentration permitted for land application

source : Colorado Department of Health. Biosolids Regulation 4.9.0. (1996)

n.d. : not detected

WTS might contain not only organic matter but also contaminants such as heavy metals. Then, we also determined heavy metal concentrations of the sludge sample (Table 3). Various standards of the heavy metal concentration are also given in the table. Copper and Zinc were detected but at a very low level. Lettuce is very sensitive to $\mathrm{Cu}$ and $\mathrm{Zn}$ elements, and also accumulates higher concentrations of heavy metals (Dolgen et al., 2004). The $\mathrm{Cu}$ and $\mathrm{Zn}$ concentrations in WTS used in these experiments were significantly less than the maximum allowable limits of Korea and the USA. Arsenic in particular remains a priority concern as an organic pollutant in sludge but the arsenic was not detected in the sludge used in this study.

\section{Changes in soil properties by sludge application}

Table 4 summarizes the changes in $\mathrm{pH}, \mathrm{EC}$ and water content of the soil samples treated with WTS at the start of the experiment and those at the harvest. As the table indicates, the water content decreased with WTS application in the VA soil, but the WTS addition of 25\% and $50 \%$ in the DG soil increased water content by $1 \%$ and $4.6 \%$, respectively. These results can be explained by the difference of the original water content in each soil sample (Table 2), as Bugbee and Frank (1985) reported that the addition of WTS improved the soil water retention. Application of WTS to soil may result in alterations in the soil $\mathrm{pH}$. The change in soil pH depends on many soil properties and the length of time after WTS application. The initial $\mathrm{pH}$ range of WTS treatments in this study varied from 5.6 to 7.0 and the $\mathrm{pH}$ after the cultivation of lettuce was increased from 0.2 to 0.5 . In particular, the $\mathrm{pH}$ ranges in both soil samples which were mixed with WTS were within the best ranges ( $\mathrm{pH}$ 5.7-7.0) of soil $\mathrm{pH}$ for lettuce growth (Malavolta, 1981). The result is in agreement with the literature of other workers, which reported that WTS increased soil pH from 5.3 in the control to 8.0 in the $100 \mathrm{~g} \mathrm{~kg}^{-1}$ WTR-amended treatment (Elliott and Singer, 1988). In addition, WTS may favorably modify the $\mathrm{pH}$ of soils (Elliott and Dempsey, 1991). Therefore, WTS was not considered to be detrimental to soil $\mathrm{pH}$. WTS addition did not significantly affect electrical conductivity (EC) for the VA soil, but treatments of the DG soil increased with WTS percentage. When compared with the initial EC of the treatments, the EC of the DG soil treatments increased after the harvest, but the VA soil except for the 50\% treatment of WTS tended to decrease. The EC of the DG soil treatments may be increased due to mineralization of organic nitrogen by applications of WTS. The EC of the both soil treatments with WTS addition after the harvest ranged from 2.2 to $3.7 \mathrm{dS} \mathrm{m}^{-1}$, being well below the $4 \mathrm{dS} \mathrm{m}^{-1}$ associated with reduced plant growth caused by soil salinity (U.S. Salinity Laboratory Staff, 1954).

\section{Plant nutrients, growth, and production}

The effects of the sludge on nutrient contents ( $\mathrm{T}-\mathrm{N}$, $\mathrm{K}, \mathrm{Ca}, \mathrm{P}$, and $\mathrm{Mg}$ ) of shoots and roots are shown in Table 5. The nutrient contents of shoots and roots by WTS addition in VA soil did not show significant differences. However, $\mathrm{K}, \mathrm{Ca}, \mathrm{P}$, and $\mathrm{Mg}$ in shoots of DG soil were on a higher level in WTS treatments of $25 \%$ and $50 \%$ than in $0 \%$ sludge treatment. Additionally, the $\mathrm{T}-\mathrm{N}$ contents in shoots and roots of DG soil apparently increased by WTS application compared to $0 \%$ sludge. This might be due to the nutrient contents contained in WTS (Table 2). The growth of lettuce was evaluated by counting the

Table 4. Change of soil $\mathrm{pH}, \mathrm{EC}$ and water content on the sludge application

\begin{tabular}{|c|c|c|c|c|c|c|}
\hline \multirow{2}{*}{ Samples } & \multirow{2}{*}{$\begin{array}{c}\text { Sludge } \\
\text { treatment (\%) }\end{array}$} & \multirow{2}{*}{$\begin{array}{c}\text { Water content } \\
(\%)\end{array}$} & \multicolumn{2}{|c|}{$\mathrm{pH}(1: 5)$} & \multicolumn{2}{|c|}{$\mathrm{EC}\left(\mathrm{dS} \mathrm{m} \mathrm{m}^{-1}\right)$} \\
\hline & & & Before & After & Before & After \\
\hline \multirow{4}{*}{ VA soil } & 0 (NPK) & 26.3 & 5.6 & 5.8 & 3.2 & 3.0 \\
\hline & 0 & 26.3 & 5.6 & 5.8 & 2.9 & 2.7 \\
\hline & 25 & 21.8 & 5.7 & 5.9 & 2.7 & 2.6 \\
\hline & 50 & 16.8 & 5.7 & 5.9 & 2.8 & 3.7 \\
\hline \multirow{4}{*}{ DG soil } & 0 (NPK) & 3.0 & 6.5 & 6.9 & 0.4 & 1.1 \\
\hline & 0 & 3.0 & 7.0 & 7.2 & 0.2 & 0.4 \\
\hline & 25 & 4.0 & 6.2 & 6.6 & 1.2 & 2.2 \\
\hline & 50 & 7.6 & 6.1 & 6.6 & 1.7 & 2.8 \\
\hline
\end{tabular}


Table 5. Nutrient contents of lettuce plants grown on soils mixed with different sludge applications

(unit: \% dry matter)

\begin{tabular}{|c|c|c|c|c|c|c|c|c|c|c|c|}
\hline \multirow{2}{*}{ Samples } & \multirow{2}{*}{$\begin{array}{c}\text { Sludge } \\
\text { treatment (\%) }\end{array}$} & \multicolumn{5}{|c|}{ Shoots } & \multicolumn{5}{|c|}{ Roots } \\
\hline & & $\mathrm{T}-\mathrm{N}$ & $\mathrm{K}$ & $\mathrm{Ca}$ & $\mathrm{P}$ & $\mathrm{Mg}$ & $\mathrm{T}-\mathrm{N}$ & $\mathrm{K}$ & $\mathrm{Ca}$ & $\mathrm{P}$ & $\mathrm{Mg}$ \\
\hline \multirow{4}{*}{ VA soil } & 0 (NPK) & 3.2 & 4.0 & 1.0 & 0.4 & 0.4 & 1.7 & 2.7 & 0.5 & 0.3 & 0.3 \\
\hline & 0 & 2.7 & 4.7 & 0.9 & 0.4 & 0.3 & 2.0 & 2.7 & 0.5 & 0.3 & 0.3 \\
\hline & 25 & 3.0 & 3.7 & 1.1 & 0.3 & 0.3 & 2.1 & 2.5 & 0.5 & 0.2 & 0.2 \\
\hline & 50 & 3.3 & 4.4 & 1.2 & 0.4 & 0.4 & 1.7 & 2.5 & 0.4 & 0.3 & 0.3 \\
\hline \multirow{4}{*}{ DG soil } & 0 (NPK) & 1.2 & 2.1 & 1.1 & 0.3 & 0.3 & 0.5 & 0.8 & 0.4 & 0.2 & 0.4 \\
\hline & 0 & 1.4 & 1.9 & 1.1 & 0.3 & 0.3 & 0.4 & 0.5 & 0.2 & 0.2 & 0.1 \\
\hline & 25 & 3.3 & 3.6 & 1.3 & 0.6 & 0.6 & 1.8 & 1.5 & 0.4 & 0.2 & 0.3 \\
\hline & 50 & 2.8 & 3.4 & 1.2 & 0.3 & 0.4 & 1.7 & 1.4 & 0.4 & 0.2 & 0.3 \\
\hline
\end{tabular}

Table 6. Growth characteristics of lettuce on the different sludge application

\begin{tabular}{|c|c|c|c|c|c|c|c|c|c|c|}
\hline \multirow[b]{2}{*}{ Samples } & \multirow{2}{*}{$\begin{array}{c}\text { Sludge } \\
\text { treatment (\%) }\end{array}$} & \multirow{2}{*}{$\begin{array}{l}\text { Leaf number } \\
\text { (per plant) }\end{array}$} & \multirow{2}{*}{$\begin{array}{l}\text { Leaf length } \\
\quad(\mathrm{cm})\end{array}$} & \multirow{2}{*}{$\begin{array}{l}\text { Leaf width } \\
\quad(\mathrm{cm})\end{array}$} & \multicolumn{4}{|c|}{ Fresh weight $\left(\mathrm{g}\right.$ plant ${ }^{-1}$ ) } & \multicolumn{2}{|c|}{ Yield $\left(\mathrm{kg} 10 \mathrm{a}^{-1}\right)$} \\
\hline & & & & & Shoots & Roots & Total & $\begin{array}{c}\text { Relative } \\
\text { value (\%) }\end{array}$ & Total & $\begin{array}{c}\text { Relative } \\
\text { value (\%) }\end{array}$ \\
\hline \multirow{4}{*}{ VA soil } & 0 (NPK) & $25.0 \mathrm{~ns}$ & $9.6 a^{*}$ & $15.2 \mathrm{~ns}$ & $46.2 \mathrm{a}$ & 7.0ns & $53.1 \mathrm{a}$ & 100.0 & $2307.5 \mathrm{a}$ & 100 \\
\hline & 0 & 19.0ns & $7.5 \mathrm{ab}$ & $11.8 \mathrm{~ns}$ & $30.0 \mathrm{ab}$ & $4.6 \mathrm{~ns}$ & $34.6 \mathrm{ab}$ & 65.2 & $1501.3 \mathrm{ab}$ & 65 \\
\hline & 25 & $17.3 \mathrm{~ns}$ & $6.8 \mathrm{~b}$ & $9.8 \mathrm{~ns}$ & $12.6 \mathrm{~b}$ & $3.1 \mathrm{~ns}$ & $15.7 \mathrm{~b}$ & 29.6 & $631.2 \mathrm{~b}$ & 27 \\
\hline & 50 & $21.3 \mathrm{~ns}$ & $7.8 \mathrm{ab}$ & $12.0 \mathrm{~ns}$ & $26.8 \mathrm{ab}$ & $5.6 \mathrm{~ns}$ & $32.4 \mathrm{ab}$ & 61.0 & $1340.3 \mathrm{ab}$ & 58 \\
\hline \multirow[t]{2}{*}{ Sig. F } & & - & 0.5 & - & 0.5 & - & 0.5 & & 0.5 & \\
\hline & $0(\mathrm{NPK})$ & $18.3 \mathrm{~ns}$ & $12.2 \mathrm{a}$ & $9.5 \mathrm{a}$ & $14.0 \mathrm{~ns}$ & $4.7 \mathrm{a}$ & $18.7 \mathrm{~ns}$ & 100.0 & $700.7 \mathrm{~ns}$ & 100 \\
\hline \multirow{3}{*}{ DG soil } & 0 & $13.7 \mathrm{~ns}$ & $6.5 b$ & $4.4 \mathrm{~b}$ & $2.3 \mathrm{~ns}$ & $0.8 \mathrm{ab}$ & $3.1 \mathrm{~ns}$ & 16.6 & $113.7 \mathrm{~ns}$ & 16 \\
\hline & 25 & $19.0 \mathrm{~ns}$ & $7.2 \mathrm{~b}$ & $5.6 b$ & $12.2 \mathrm{~ns}$ & $2.7 \mathrm{~b}$ & $14.9 \mathrm{~ns}$ & 79.8 & $613.2 \mathrm{~ns}$ & 88 \\
\hline & 50 & $16.7 \mathrm{~ns}$ & $8.2 \mathrm{~b}$ & $6.5 \mathrm{~b}$ & $12.3 \mathrm{~ns}$ & $3.4 \mathrm{c}$ & $15.5 \mathrm{~ns}$ & 82.9 & $608.5 \mathrm{~ns}$ & 87 \\
\hline Sig. F & & - & 0.01 & 0.01 & - & 0.01 & - & & - & \\
\hline
\end{tabular}

ns : not significant

*Mean followed by the same letter within the same column is not statistically different (Dunkan's test, $p<0.05$ ).

numbers of leaves, by simply measuring the length and width of the leaves, and by weighing the shoots and roots. The results are presented in Table 6. The most superior growth properties in both soil treatments were observed in the 0\% (NPK) WTS ratio, which is the treatment applied N-P-K fertilizer. The largest leaf number, leaf length and leaf width in the VA soil was observed in 0\% (NPK), followed by 50\% WTS (21.3, 7.8 and 12.0) and $0 \%$ sludge (19.0, 7.5 and 11.8). In the DG soil, the leaf number was the largest in the $25 \%$ WTS treatment, but leaf length and leaf width were the largest in $0 \%$ (NPK) WTS. Compared with 0\% WTS ratio, the yield for the WTS treatments of $25 \%$ and $50 \%$ in the VA soil decreased $38 \%$ and $7 \%$, respectively, but the yield in the DG soil increased $72 \%$ and $71 \%$, respectively. This means that WTS is not necessarily effective in each soil. The effects of WTS utilization as a soil amendment for various vegetables have also been reported by many scientists. Dolgen et al. (2004) found that maximum plant growth (both in shoots and roots weights) of iceberg lettuce is obtained from the $75 \%$ sludge treatment (corresponding to $496 \mathrm{t} \mathrm{ha}^{-1}$ sludge application). Kim et al. (2002) also demonstrated the beneficial effects of lettuce growth that the alum sludge treatment of the sandy clay loam soil increased the mass of shoots and roots, and enhanced the roots elongation. Application of WTS at the rates of 20 and $100 \mathrm{~g} \mathrm{~kg}^{-1}$ to silt loam enhanced tomato (Lycopersicon esculentum) growth (Elliott and Singer, 1988). Rengasamy et al. (1980) reported the maize (Zea mays L.) grown in WTS amended soil gave the highest yield at WTS addition of $0.8 \mathrm{~g} \mathrm{~kg}^{-1}$. In three different alkaline soils (clay, calcareous, and sandy), WTS application of $30 \mathrm{~g} \mathrm{~kg}^{-1}$ produced greater plant dry matter yield of corn (Zea mays) without creating phosphorus deficiency and Al phytotoxicity (Mahdy et al. 2007). Therefore, the increase in yield and growth was attributed to an improved soil nutrient status and to soil structure improvement following the sludge addition.

\section{CONCLUSIONS}

WTS has potential for environmental land application as a soil amendment and a plant growth medium. The present study was carried out to evaluate the possibility of improving soil samples and lettuce growth by applications of WTS. Main chemical compositions, physico-chemical properties, and heavy metal concentrations of WTS used for this experiment indicated that WTS would not present a problem of any hazardous and adverse effects in land applications. WTS was a suitable material for the improvement of the physical and chemical properties of DG soil. In fact, the lettuce yield of the 
DG soil treatments in this experiment increased with the addition of $25 \%$ and 50\% WTS, while in the VA soil, the yield for $25 \%$ and 50\% WTS treatments decreased in comparison with the 0\% WTS addition. These results also indicate that soil conditions with WTS are not effective in the VA soil. Therefore, land disposal of WTS to the VA soil was not recommended.

From these observations it is concluded that WTS can be recommended for use in organic matter deficient soils as an agricultural substitute and a low level fertilizer, or as a soil substitute for land reclamation.

\section{REFERENCES}

Aggelides, S. M. and P. A. Londra 2000 Effects of compost produced from town wastes and sewage sludge on the physical properties of a loamy and clay soil. Bioresource Technol., 71(3): 253-259

Babatunde A. O. and Y. Q. Zhao 2007 Constructive approaches toward water treatment works sludge management-An international review of beneficial reuses. Critical Reviews in Environmental Science and Technol., 37: 129-164

Basibuyuk M. and D. G. Kalat 2004 The use of waterworks sludge for the treatment of vegetable oil refinery industry wastewater. J. Environ. Technol., 25(3): 373-380

Basta N. T., R. J. Zupancic and E. A. Dayton 2000 Evaluating Soil Tests to Predict Bermudagrass Growth in Drinking Water Treatment Residuals with Phosphorus Fertilizer. J. environmental quality, 29: 2007-2012

Bremner J. M. and C. S. Mulvaney. 1982 Nitrogen-Total. In "Methods of soil analysis. Part 2 Chemical and microbiological properties", ed. by A. L. Page, R. H. Miller and D. R. Keeney, Agronomy 9(2), Am. Soc. of Agron., Madison, Wisconsin, pp 595-624

Bugbee G. J. and C. R. Frink 1985 Alum sludge as a soil amendment-Effects on soil properties and plant growth, Bulletin 827. Connecticut Agric. Exp. Stn, New Haven, USA

Clapp C. E, S. A. Stark, D. E. Clay and W. E. Larson 1986 Sewage sludge organic matter and soil properties-The Role of Organics Matter in Modern Agriculture. Martinus Nijhoff Publications, The Hague, Netherland, pp. 209-253

Colorado Department of Public Health and Environment 1996 In "Revised biosolids regulation 4.9.0.", Colorado Dep. of Pubilic Health and Environ., Denver, USA

Dharmappa H. B., A. Hasia and P. Hagare 1997 Water treatment plant residuals management. Water Sci. Technol., 35(8): $45-56$

Dolgen D., M. N. Alpaslan and N. Delen 2004 Use of an agroindustry treatment plant sludge on iceberg lettuce growth. Ecological Engineering, 23: 117-125

Elliott H. A. and B. A. Dempsey 1991 Agronomic effects of land application of water treatment sludge. J. Am. Water Works Assoc., 83(4): 126-131

Elliott H. A. and L. M. Singer 1988 Effect of water treatment sludge on growth and elemental composition of tomato shoots. Commun. Soil Sci. Plant Anal., 19(3): 345-354

Flint, A. L. and L. E. Flint 2002 Particle density. In "Methods of Soil Analysis. Part 4. Physical Methods", ed. by Dane, J. H. and Topp, G. C., Soil Science Society of America Book Series N0. 5, Madison, Wisconsin, pp. 229-240

Gee, G. W. and D. Or 2002 Particle size analysis. In "Methods of Soil Analysis. Part 4. Physical Methods", ed. by Dane, J. H. and Topp, G. C., Soil Science Society of America Book Series
N0. 5, Madison, Wisconsin, pp .255-293

Geertsema W. S, W. R. Knocke, J. T. Novak and D. Dove 1994 Long term effects of sludge application to land. J. American Water Works Association, 1: 64-74

Heil D. M. and K. A. Barbarick 1989 Water treatment sludge influence on the growth of sorghum-sudangrass. J. Environ. Qual., 18(3): 292-298

Japanese Society of Soil Science and Plant Nutrition 2003 Standard Method of Soil-Environmatal Analyses, Hakuyusha, Tokyo

Kim J. G., S. S. Lee, H. S. Moon, I. M. Kang 2002 Land application of alum sludge from water purification plant to acid mineral soil treated with acidic water. Japanese Society of Soil Sci. and Plant Nutri., 48(1): 15-22

Logan T. J and B. J. Harrison 1995 Physical characteristics of alkaline stabilized sewage sludge (N-Viro soil) and their effects on soil physical properties. J. Environ. Qual. 24: 153-164

Mahdy A. M., E. A., Elkhatib and N. O. Fathi 2007 Drinking water treatment residuals as an amendment to alkaline soils: Effects on the growth of corn and phosphorus extractability. Int. $J$. Environ. Sci. Technol., 4: 489-496

Malavolta, E. 1981 Manual de Química Agrícola (Manual of agricultural chemistry) - Adubos e Adubação, Ceres: São Paulo, Brazil, p. 478

Ministry of Environment in Korea 2005 Water treatment statistics-2004. Ministry of Environment, (Korea)

Moodley M. and J. C. Hughes 2005 The effects of a polyacrylamide-derived water treatment residue on the hydraulic conductivity, water retention and evaporation of four contrasting South African soils and implications for land disposal. Water Science \& Technol., 54(5): 227-234

Rengasamy P., J. M. Oades and T. W. Hancock 1980 Improvement of soil structure and plant growth by addition of alum sludge. Commun. Soil Sci. Plant Anal., 11(6): 535-545

Rensburg V. L. and T. L. Morgenthal 2003 Evaluation of water treatment sludge for ameliorating acid mine waste. $J$ Environ. Qual., 32: 1658-1668

Sánchez Monedero M. A., C. Mondini, M. de Nobili, L. Leita and A. Roig 2004 Land application of biosolids. Soil response to different stabilization degree or treated organic matter. Waste Management, 24(4): 325-332

Schollenberger C. J. and R. H. Simon 1945 Determination of exchange capacity and exchangeable bases in soil-ammonium acetate method. Soil Sci., 59: 13-24

Skene, T. M., J. M. Oades and G. Kilmore 1995 Water treatment sludge: A potential plant growth medium. Soil Use Manage., 11: $29-33$

U.S. Environmental Protection Agency (USEPA) 1995 Process Design Manual: Land Application of Sewage Sludge and Domestic Septage, Office of Research and Development. EPA/625/R-95/001, Washington, D.C., USA

U.S. Environmental Protection Agency (USEPA) 1983 Process design manual. Land application of municipal sludge. EPA-625/1-83-016, Cincinnati, Ohio, USA

U.S. Salinity Laboratory Staff 1954 Diagnosis and improvement of saline and alkali soils, U.S. Department of Agriculture, Handbook 60, Government Printing Office, Washington, DC., USA

Wang M. J. 1997 Land application of sewage sludge in China. The science of the total environ., 197: 149-160

Zhao, Y. Q., M. Razali, A. O. Babatunde, Y. Yang and M. Bruen 2006 A multi-pronged approach to using dewatered alum sludge to immobilize a wide range of phosphorus contamination. Oral presentation at 5th IWA World Water Congress, Beijing, China 